\title{
25. DOLOMITIZATION IN EARLY PLIOCENE PELAGIC LIMESTONES, SITE 374, IONIAN ABYSSAL PLAIN
}

\author{
Daniel Bernoulli, Geological Institute, University of Basel, Switzerland \\ and \\ Frédéric Mélières, Laboratoire de Géologie Dynamique, Université Pierre et Marie Curie, 75230 Paris, \\ Cedex 05, France
}

\begin{abstract}
At Site 374, Ionian Abyssal Plain, about 8.5 meters of light olive to yellowish gray, partly calcitic dolomicrites are intercalated between early Pliocene pelagic nannofossil marls to oozes and late Messinian dark gray, homogeneous dolomitic mudstones. Sedimentary textures and structures and relics of coccoliths and planktonic foraminifers indicate that the dolomicrites result from dolomitization of early Pliocene nannofossil ooze. Dolomite occurs as platy pseudohexagonal crystals replacing sediment, growing across and within tests of planktonic foraminifers and lining molds in completely dolomitized sediment. The very important development of (0001)-faces in these crystals give rise to unusually high intensities of (000l)-peaks in X-ray diffractograms. The unusual crystal morphology is explained by an inhibiting effect on crystal growth perpendicular to $(0001)$ of certain ions, mainly $\mathrm{Cl}^{-}$, in the highly saline interstitial brine.
\end{abstract}

\section{INTRODUCTION}

In the central Ionian basin the early Pliocene is generally present as pelagic to hemipelagic nannofossil marl and ooze (Biscaye et al., 1971; Ryan, Hsü, et al., 1973). At Site 374 (Figure 1) some 30 meters of early Pliocene varicolored, mostly reddish brown to tan nannofossil marls to oozes have been found (Cores $8-10)$. These have been deposited in a generally oxidized environment; benthic foraminifers indicate water depth in excess of 1200 meters (see Site 374 Report, this volume). Intercalated sapropelic layers, which essentially are organic-rich nannofossil marls devoid of benthic foraminifers, are indicative of episodic stagnation of the bottom waters. (For data on lithology and mineralogy of Site 374, see Site 374 Report, this volume).

The hemipelagic and pelagic sediments of the Pliocene are separated from the underlying dark gray dolomitic marlstone of the late Messinian by about 8.5 meters of slightly calcitic dolomite (Core 11, Section 1) and dolomite (Core 11, Section 2) of which about 2.30 meters have been recovered. Macroscopically the facies of these dolomites is very similar to that of the overlying Pliocene marls and oozes (Core 9, Figure 2) and, in fact, mineralogic analysis (conducted by F. M.) together with investigations with the light microscope and the SEM (conducted by D. B.) show that the dolomites result from replacement of a pelagic carbonate sediment by fine-grained dolomite. This dolomite is generally present as pseudohexagonal plates, up to 40 $\mu \mathrm{m}$ across, with a tendency towards more rhombohedral and blocky crystals downcore.
The facies of the dolomites of Core 11 is fundamentally different from that of the underlying dark gray, homogeneous and barren dolomitic marls of the upper Miocene (Cores 12-15). Although the actual contact has not been sampled, a gradual transition between the two facies over a few meters at best is unlikely and a disconformity similar to that at Site 125 is most probable (Ryan, Hsü, et al., 1973).

\section{FACIES}

A generalized lithologic log including mineralogical analysis is given in Figure 3. The upper part of Core 11 , Section 1, consists of light olive gray to yellowish gray, very fine calcitic dolomicrite with faint mottling and some darker bands of greenish gray color. Tiny voids observable on the core photographs (see Figure 4) can be identified as relics of planktonic foraminifers (see Plates 1 to 3 ). Two intercalations of black sapropelic sediments are present; both show tiny burrows of Chondrites types which are filled by light colored pelagic sediment piped down from above. The higher sapropel also shows burrows of Zoophycos type, and the underlying sediment in turn exhibits burrows which are filled by dark sediment (Figure 5).

Core 11, Section 2 contains no calcitic remains but the overall facies is identical. It consists of light olive gray to greenish gray and pale blue-green dolomicrite, homogeneous to faintly mottled, in which planktonic foraminifers appear as molds (Figure 4 and Plate 4). Burrows are of Chondrites and Zoophycos type. Prominent sapropels are present at $112-121 \mathrm{~cm}$ and at the bottom of the core. They are distinctly laminated and rich in molds of planktonic foraminifers (Figure 4). 


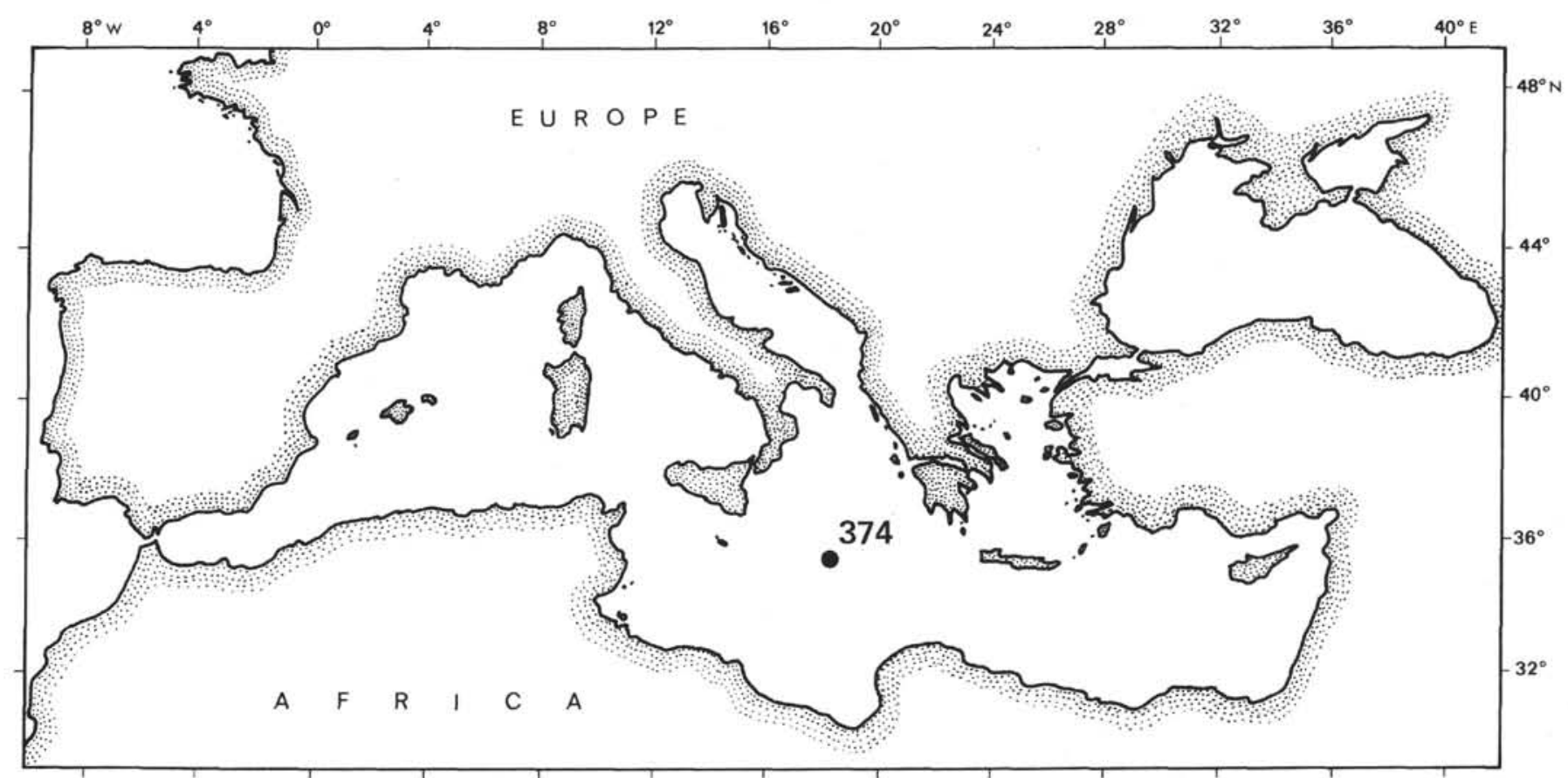

Figure 1. Location of Site 374.

Some brecciated fragments of gypsum are present (Sample 11-2, 48-60 cm) which are interpreted as diagenetic.

The depositional textures, the sedimentary structures, and the types of burrowing are identical with those of the overlying lower Pliocene: the depositional environment of the dolomitized sediment obviously was essentially the same as that of the lower Pliocene in general.

\section{MINERALOGY}

Quantitative X-ray mineralogical analyses have been carried out on 23 samples (bulk) taken at small intervals along Core 11. The results are given in Figure 3.

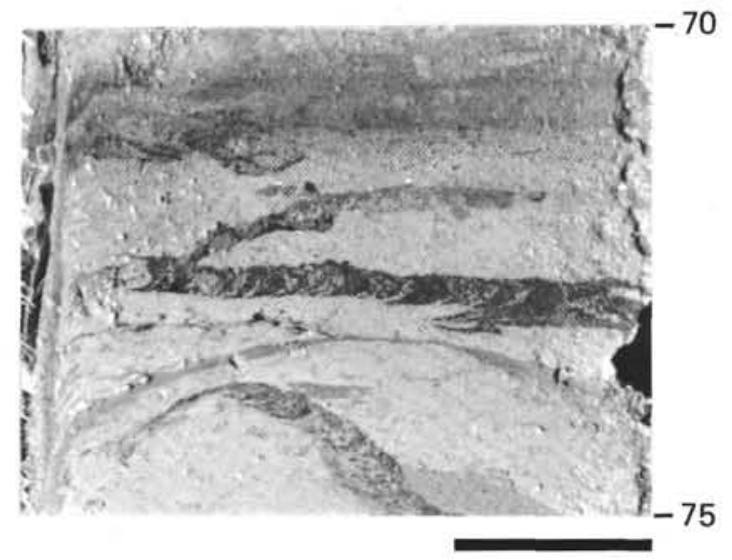

Figure 2. Light gray nannofossil marl of lower Pliocene with burrows of Zoophycos-type filled by darker sediment. Core 374-9-3, scale bar: $2 \mathrm{~cm}$.
Generally, most of the sediment consists of carbonate minerals the importance of which ranges between $50 \%$ and $80 \%$. In the lower part of the core (Section 2) only dolomite is present, whereas in the upper part (Section 1) both dolomite and calcite are present; the amount of the latter decreases from the top (30\%) to the bottom of Section $1(0 \%)$. The total amount of carbonate is approximatively constant along the entire length of the core, suggesting that calcite is replaced by dolomite.

Mineralogically, the calcite always shows very good crystallinity [L $\left.1 / 2(10 \overline{1} 4)=0.17^{\circ} 2 \theta \mathrm{CuK}_{\propto}\right]$ and is completely devoid of $\mathrm{MgCO}_{3}$. This suggests that some recrystallization took place after the deposition of biogenic calcitic material (coccoliths and foraminifers), the crystallinity of which ranges usually around $0.20^{\circ}$. $2 \theta$ (L $1 / 2$ (1014), with a $\mathrm{MgCo}_{3}$ content which is generally 1 to $2 \%$ (low $\mathrm{Mg}$-calcite).

The dolomite is hypercalcic, with a $\mathrm{Ca}$ content ranging between 0.53 and 0.55 ; these variations (see Figure 3 ) apparently are not related to the variations of the other mineralogical parameters of the core. On the X-ray diffractograms, (000 \&)-peaks of this dolomite show unusually high intensities; for (0006) this intensity, measured versus (10i14) peak intensity, is 10 to 15 times higher than for average dolomites (classical rhombohedral faces). This fact is related to the important development of $(000 \overline{1})$ faces giving the dolomite crystallites a morphology of pseudohexagonal flakes (Plate 4).

Beside carbonates, the sediments of Core 11 contain quartz, K-feldspar, attapulgite, illite, kaolinite, and smectite, all of which quantitatively fluctuate exactly in phase along the core, suggesting that the entire assemblage is detrital. 


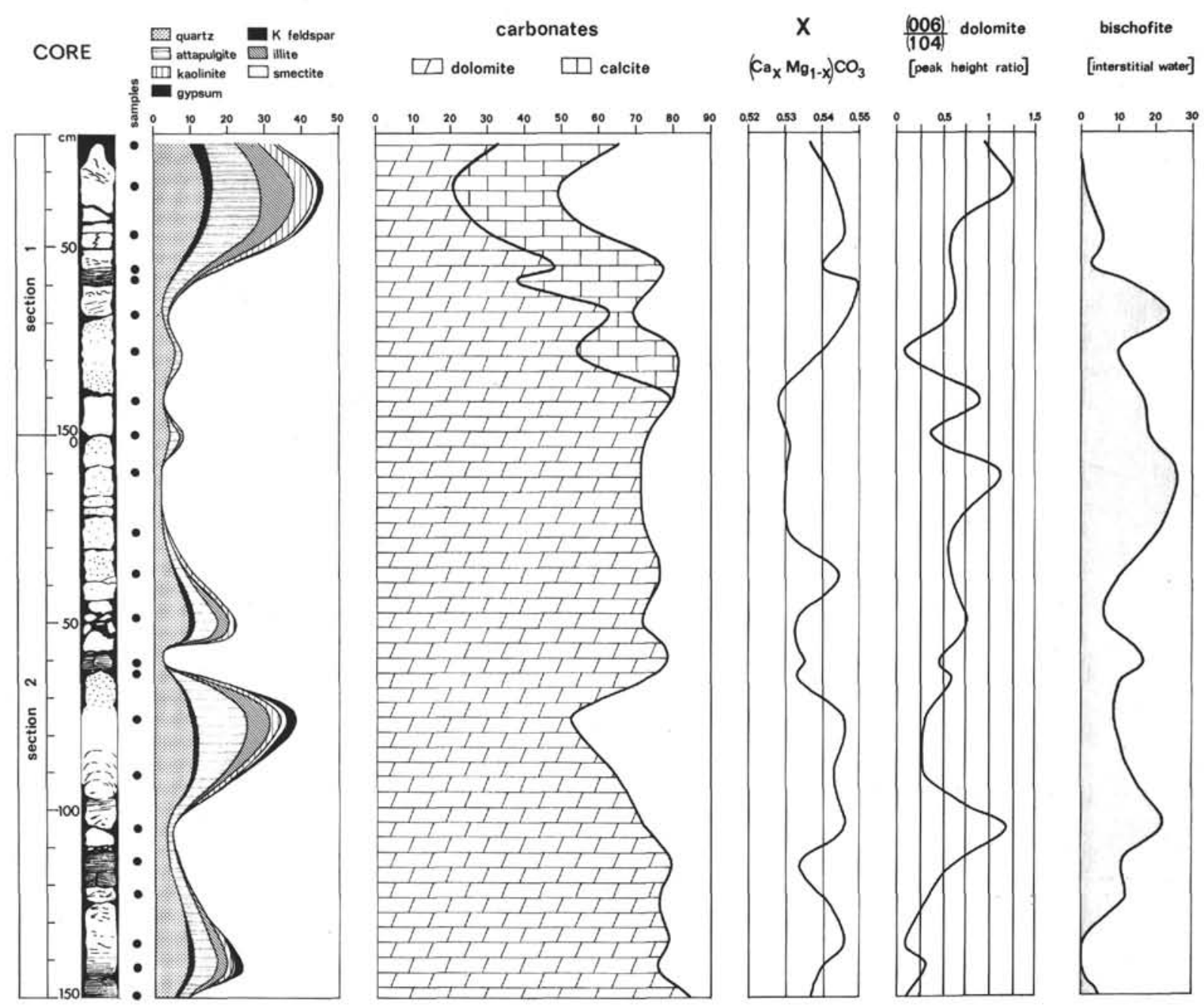

Figure 3. Lithological succession and mineralogy of Core 11, Site 374. Lower Pliocene.

Sapropelic layers are characterized by a very low terrigenous detrital content confirming that the depositional environment was stagnant.

Besides the minerals mentioned above (carbonates and silicates) the X-ray diffractograms show the presence of bischofite $\left(\mathrm{MgCl}_{2}, 6 \mathrm{H}_{2} \mathrm{O}\right)$ the amount of which may reach $25 \%$ of the bulk mineralogy. However, bischofite does not exist as a mineral in the sediment; it was formed in the laboratory by evaporation of interstitial water when the samples were dried in the oven $\left(40^{\circ} \mathrm{C}\right)$.

The mineralogical assemblage of the detrital fraction (qualitatively as well as quantitatively) and the carbonate content allow us to compare Core 11 with the overlying lower Pliocene, the sediments of which show very similar mineralogical features (Mélières et al., this volume). Moreover, the mineralogy of Core 11 strongly contrasts with that of the underlying dark gray dolomitic marls of the uppermost Miocene, which are characterized by an important terrigenous detrital fraction ( $80 \%$ of the bulk), barren of attapulgite.

\section{SEM OBSERVATIONS}

Down to about $140 \mathrm{~cm}$, Section 1 of Core 11 contains, besides about $40 \%$ of fine detrital minerals, varyi.ig amounts of calcite (a few to about $30 \%$ ) and dolomite (20-65\%) (Figure 3). The sediment is composed of fine-grained carbonate, coccoliths, anhedral carbonate grains, and fine platy dolomite crystals; more or less altered tests of planktonic foraminifers constitute the coarse fraction (Plate 1).

The coccoliths are generally well preserved and do not show signs of dissolution; the elements of the distal shield and the central distal area generally show some secondary overgrowth of syntaxial calcite cement (Plate 1, Figure 13), but the two shields are not welded by overgrowth (Plate 1, Figures 4, 5, 8, 14) and the elements of the proximal shields are free from syntaxial cements. Discoasterids show moderate (Plate 1 , Figure 15 ) to heavy overgrowth.

The foraminiferal tests show different stages of dissolution even within one and the same individual (Plate 1, Figure 8). In the shell of adult planktonic foraminifers, two or three layers can be distinguished (Bé et al., 1975). The inner or proximal layer consists of fine anhedral microgranules (microgranular layer, e.g., Plate 1, Figure 5); this is overlain by a layer with radially arranged prismatic crystallites (subrhombic layer) which eventually grade outwards into large prismatic crystals with euhedral crystal faces (euhedral 


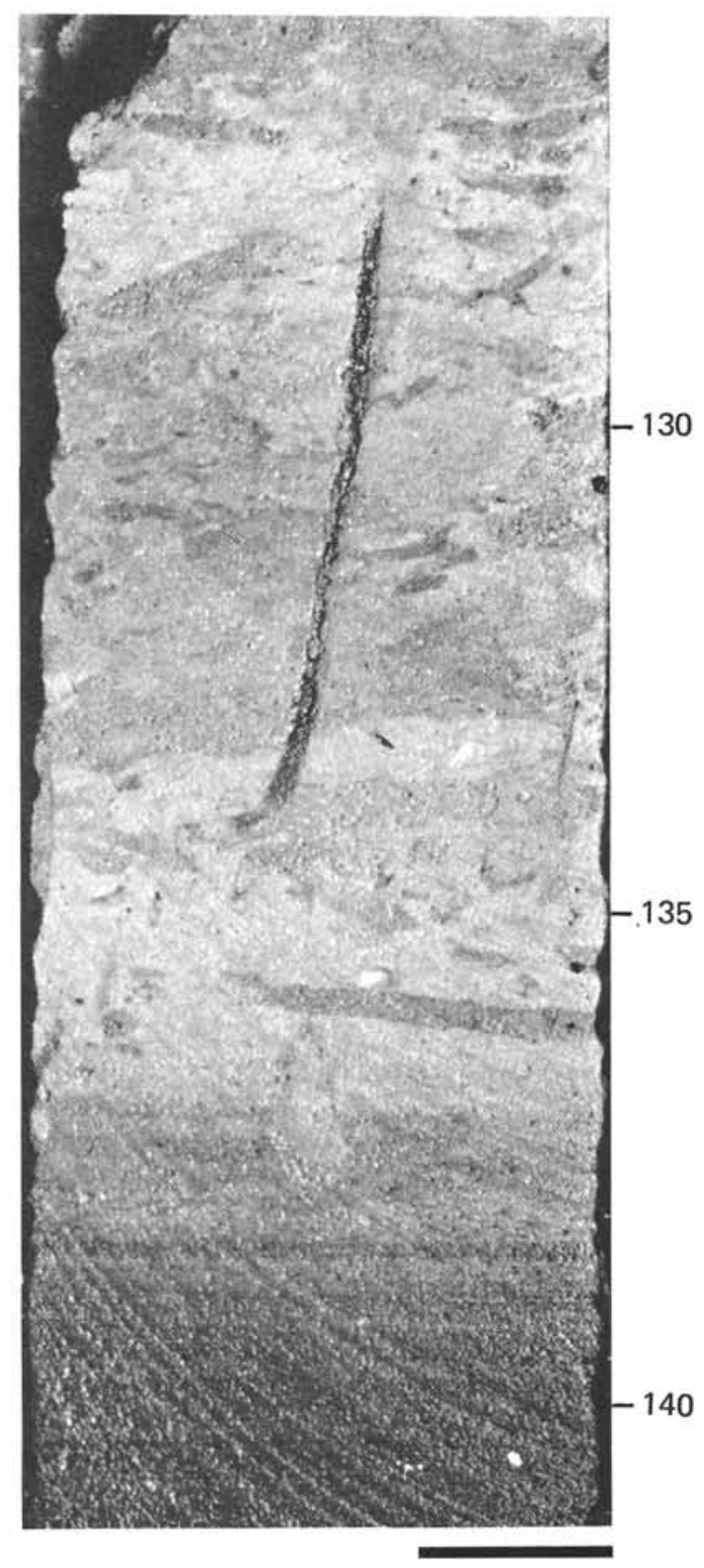

Figure 4. Pale blue-green, fine-grained dolomicrite mottled by intense burrowing and containing molds of planktonic foraminifers, grading downward into laminated sapropelic dolomicrite. Lower Pliocene, Section 37411-2, scale bar: $2 \mathrm{~cm}$.

layer Bé et al., 1975; or calcite crust, Bé and Erickson, 1963; Plate 1, Figures 9, 10). In Plate 1, Figures 5 and 8 , upper left, it appears that the subrhombic layer is dissolved earlier than the microgranular layer and the outer part of the euhedral layer. Typical solution etching surfaces on the inner side of the microgranular layer are visible in Plate 1, Figures 8, 11, and 12.

Tiny crystals of platy dolomite appear to have grown within the fine sediment (e.g. Plates 1, 2). Larger, well developed pseudohexagonal crystals with well developed $(0001)$ crystal faces, up to $50 \mu \mathrm{m}$ across and a few microns thick are present in the intraskeletal voids of the planktonic foraminifers (Plate 1, Figures

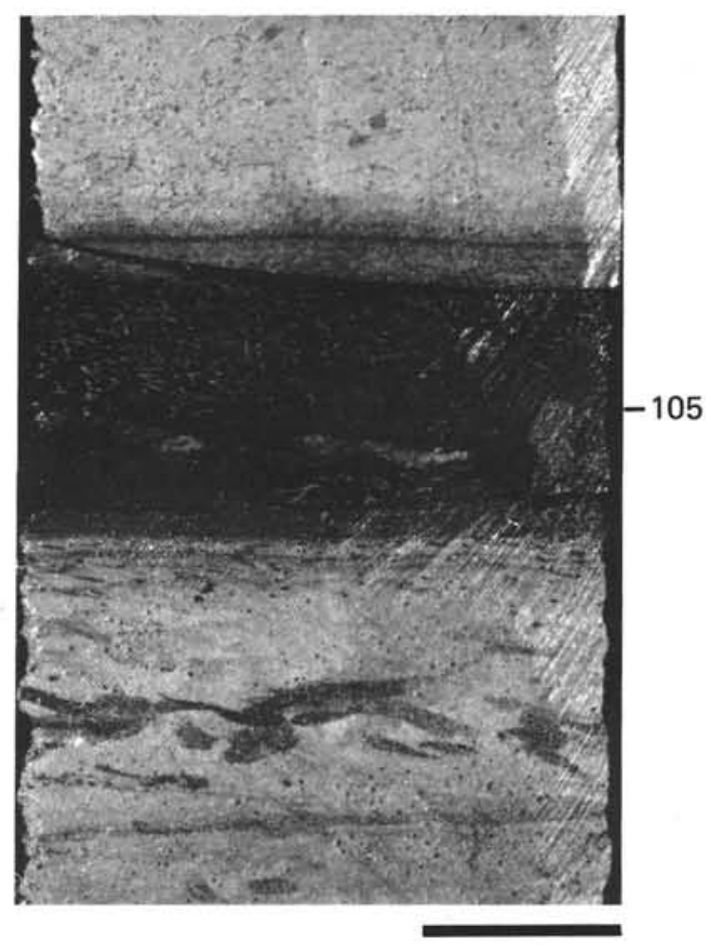

Figure 5. Light olive-gray to yellowish gray, very fine calcitic dolomicrite with an intercalation of black sapropelic dolomicrite. The sapropelic sediment shows tiny burrows of Chondrites- and Zoophycos-type which are filled from above by light colored sediment, in turn the burrows in the underlying sediment are filled by dark sediment. Tiny voids are relics of planktonic foraminifers. Lower Pliocene, Core 374-11-1, scale bar: $2 \mathrm{~cm}$.

1-6; Plate 3, Figures 1, 2). Plate 1, Figure 8 clearly shows that these have not only grown free in the pore space but also across and replacing the wall of the foraminifers. Sometimes coccoliths are enveloped or replaced by dolomite and appear as half-drowned floatsam on the surface of the crystals (cf. Matter et al., 1975, pl. 6, fig. 11). The mineralogic and crystallographic characteristics of the dolomite are described below.

Below Section 1, $141 \mathrm{~cm}$, no calcite is present in Core 11. In the upper part of Core 11, Section 2 the fine carbonate sediment appears to be entirely replaced by small euhedral pseudohexagonal platy dolomite crystals, some $10 \mu \mathrm{m}$ across and one to a few microns thick (e.g., Plate 2, Figures 2, 5). Molds of planktonic foraminifers are clearly visible throughout (Plate 2, Figures 1-6); they are lined by larger, platy dolomite crystals up to $40 \mu \mathrm{m}$ across and several microns thick (Plate 4, Figure 1). The dolomite crystals in both the matrix and the molds are interlocking, giving the sediment a stable cardhouse texture (Plate 2, Figure 4).

Between 97 and $107 \mathrm{~cm}$ in Core 11, Section 2, the habit of the dolomite crystal changes; (0001) crystal faces are somewhat less common and the crystals show a more blocky appearance with sometimes well devel- 
oped rhombohedral or prismatic crystal faces (Plate 2, Figures 7-16; Plate 3, Figures 3, 4). Molds of planktonic foraminifers, sometimes lined by framboidal pyrite (Plate 2, Figure 12) are clearly recognizable throughout the section.

\section{CRYSTALLOGRAPHY}

Non-oriented X-ray powder diffractograms of the dolomite of Core 11 show an important, quite unusual, intensity of $(000 \ell)$ reflexions, mainly $(0006)$ and (00012), and to a lesser extent of (0003) (not quoted in ASTM 11-78 card) and (0009) (Plate 4). This is due to the important development of (0001) crystal faces, perpendicular to the c-axis, giving rise to the spectacular morphology of pseudohexagonal flakes which, to the authors' knowledge, have never been described in a sedimentary environment.

The reason for this preferential development of (0001) crystal faces is probably to be seen in the nature of the chemical environment in which the dolomite crystals grew. Artificial growth experiments have shown that in presence of certain ions $\left(\mathrm{Li}^{+}, \mathrm{Cl}^{-}\right.$ for instance), calcite crystals grow in hexagonal flakes: " $\mathrm{Li}^{+}$and $\mathrm{Cl}$ ions, much smaller than $\mathrm{Ca}^{++}$and $\mathrm{CO}_{3}$ ", may adsorb on the non-compact (0001) faces of calcite, creating a layer with $2 \mathrm{P}$. B. C. (periodic bond face), thus of F type (flat face) (Hartmann, 1965), as a consequence crystal growth perpendicular to $(0001)$ is greatly hampered allowing this face to develop markedly." (Lefaucheux, 1971).

In the case of the dolomite in Core 11, it is probable that such a mechanism has to be invoked in relation to the very high $\mathrm{Mg}^{++}$and $\mathrm{Cl} \ell^{-}$content of the interstitial water. The actual salinity of this interstitial water is $38 \%$ (mean value) and solid residue after evaporation consists of some $90 \%$ bischofite and $10 \%$ halite (XRD). Crystal growth perpendicular to (0001), i.e., in the direction of the c-axis, is inhibited by the mentioned mechanism and the crystals have grown along (10I4) faces which limit the flakes, giving them a pseudohexagonal contour. These flakes offer a foliaceous texture which can be easily seen at high magnification (Plate 4). Each thin plate, of some $1000 \AA$ in thickness, appears to have been developed for itself, without relationship to its immediate neighbor, except epitaxy. At the scale of the flake (n. $10 \mu \mathrm{m})$, the result is an imperfect hexagonal contour (Plates 1, 2, 4).

The influence of the chemical environment on the growth morphology of dolomite crystals could not be investigated until now because, to date, dolomite crystals could not be artificially grown under sedimentary conditions.

The amount of bischofite can be related to the amount and the concentration of the interstitial water. Unfortunately, the size of the samples used for XRD analysis $(0.5 \mathrm{cc})$ did not allow determination of water content and of interstitial water geochemistry. Nevertheless, it can be seen (Figure 3), at least in the fully dolomitized section (Section 2), that the maxima of bischofite generally coincide with the maxima of the $(0006) /(1014)$ peak ratio in dolomite (which tantatively may serve as a measure for abundance of the pseudohexagonal flakes), which seems to confirm the role played by $\mathrm{Mg}^{++}$and/or $\mathrm{Cl}^{-}$ions in the development of the platy morphology.

\section{DISCUSSION}

All the depositional characteristics observed in Core 11-general facies, sedimentary structures including trace fossils, depositional texture, fossil content, and clay mineral assemblage-clearly indicate that Core 11 is part of the lower Pliocene pelagic sequence. From the underlying dark gray, homogeneous and unfossiliferous dolomitic marls, these pelagic sediments are distinct by virtue of their different clay mineral assemblage, the general facies and the presence of a rich though diagenetically altered or obliterated pelagic fauna and flora. Obviously, the dolomicrites and calcitic dolomicrites of Core 11 are the result of diagenetic alteration of a normal pelagic marl to ooze. Minor amounts of diagenetically formed dolomite occur also higher in the early Pliocene marls and oozes (Mélières et al., this volume, Müller, this volume).

In Core 11, Section 1, dolomite occurs mainly as pseudohexagonal platy crystals. These crystals appear to have grown across foraminiferal tests and sediment, replacing or enveloping earlier calcite as well as large crystals in the intraskeletal voids of the foraminifers which are heavily corroded. Typically, the prismatic layer of the planktonic foraminifers has been dissolved earlier than the microgranular layer, which, however, also shows pronounced solution etching. We interpret these solution features as contemporaneous with the growth of the dolomite crystals. Solution of calcite and growth of dolomite apparently are preceded by early diagenetic secondary over-growth of calcite on discoasterids and on the distal shields and the distal central areas of placoliths.

In Core 11, Section 2 all the primary calcitic sediment is replaced by dolomite. In the upper part of the section, dolomite appears as platy, pseudohexagonal crystals with well developed (0001) crystals faces which give rise to pronounced reflections in the X-ray diffractograms. From a crystallographic point of view, this unusual platy morphology seems to be related to the unusual chemical environment in which the crystals grew. In fact, the interstitial water is rich in $\mathrm{Mg}^{++}$and $\mathrm{Cl}^{-}$, and it is probable that these ions, adsorbed on $(0001)$ crystal faces, inhibited crystal growth in direction of the c-axis, allowing the (0001)-faces to develop markedly. Down-core, the habit of the dolomite crystals changes progressively, and more blocky crystals with rhombohedral and prismatic faces appear. This trend is not clearly understood; it is possibly related to the down-core decrease in bischofite (potential) amount as it can be seen on Figure 3.

All mineralogic, crystallographic and lithologic data suggest that the formation of dolomite in the pelagic 
sediment of Core 11 is related to the unusual composition of the interstitial water (McDuff and Gieskes, this volume). At Site 374, salinity and chlorinity show increasing trends downhole with salinities as high as $46 \%$ at the bottom of the hole and ranging from 35 to $38 \%$ in the dolomitized limestones of the lowermost Pliocene (Core 11). At this level and below, both inorganic geochemistry and X-ray diffraction analysis of evaporated interstitial waters show a very high concentration of $\mathrm{Mg}^{++}$and $\mathrm{Cl}^{-}$in the interstitial brine which also increases downhole, suggesting that the $\mathrm{Mg}$ chloride is derived from an underlying evaporite formation with highly soluble salts. Down to Core 9 (360 $\mathrm{m}$, lower Pliocene), the $\mathrm{Ca}^{++}$concentration increases more or less parallel to that of $\mathrm{Mg}^{++}$, but below this it shows an opposite trend and at the base of the dark dolomitic marls of the uppermost Miocene (Core 15, approximately $20 \mathrm{~m}$ below Core 11) the interstitial water is depleted in $\mathrm{Ca}^{++}$. This and the total lack of calcite below Core 11, Section 1, suggests that dissolution of calcite and dolomitization of pelagic sediments in Core 11 is related to the presence of interstitial waters rich in $\mathrm{Mg}^{++}$and with a $\mathrm{Mg} / \mathrm{Ca}$ ratio around 7 .

\section{ACKNOWLEDGMENTS}

D. Bernoulli thanks the Swiss National Science Foundation for support during this project (Grant 2.125-0.74). R. Guggenheim provided facilities at the SEM Laboratory at the
Geological Institute of Basel University; Mrs. L. Luginbühl operated the microscope and assisted in editing the paper.

\section{REFERENCES}

Bé, A. W. H. and Ericson, D. B., 1963. Aspects of calcification in planktonic foraminifera (Sarcodina): Ann. New York Acad. Sci., v. 109, p. 65-81.

Bé, A. W. H., Morse, J. W., and Harrison, S. M., 1975. Progressive dissolution and ultrastructural breakdown of planktonic foraminifera: Cushman Found. Foram. Res. Spec. Publ. 13, p. 27-55.

Biscaye, P. E., Ryan, W. B. F., and Wezel, F. C., 1971. Age and nature of the Pan-Mediterranean subbottom Reflector M. In Stanley, D. J., (Ed.) The Mediterranean Sea: A natural sedimentation laboratory: Stroudsburg, Pennsylvania (Dowden, Hutchinson \& Ross, Inc.)

Hartmann, P., 1965. Adsorption et croissance cristalline: C.N.R.S., Paris.

Lefaucheux, F., 1971. Modification du facies, observation de certain défauts dans les calcites synthétiques: Soc. France. Mineral. Cristallogr., Bull., v. 94, p. 100-107.

Matter, A., Douglas, R. G., and Perch-Nielsen, K., 1975. Fossil preservation, geochemistry and diagenesis of pelagic carbonates from Shatsky Rise, Northwest Pacific. In Larson, R. L., Moberly, R., et al., Initial Reports of the Deep Sea Drilling Project, Volume 32: Washington (U.S. Government Printing Office), p. 891-921.

Ryan, W. B. F., Hsü, K. J., et al., 1973. Initial Reports of the Deep Sea Drilling Project, volume 13: Washington (U.S. Government Printing Office). 



\section{PLATE 1}

Stereoscan electron micrographs of dolomitized pelagic limestone of lower Pliocene, Sample 374-11-1, 107.5-111 cm.

Figures 1, 2 Fine-grained calcitic dolomicrite with strongly corroded foraminiferal tests and euhedral platy dolomite crystals growing in and across the foraminiferal shell.

Scale bars: $1.200 \mu \mathrm{m}$.

2. $100 \mu \mathrm{m}$.

Figures 3, 4 Planktonic foraminifer with corroded prismatic layer and large platy dolomite crystals growing across and inside the shell. Dolomite crystals show well developed (0001)-planes.

Scale bars: $3.20 \mu \mathrm{m}$.

4. $10 \mu \mathrm{m}$.

Figure 5 Foraminiferal shell wall with corroded microgranular layer and almost entirely dissolved prismatic layer. Placoliths show some syntaxial overgrowth on elements of distal shield but no welding of shields. Large dolomite crystal growing inside and across foraminiferal test. Scale bar, $10 \mu \mathrm{m}$.

Figures 6, 7 Strongly corroded foraminiferal test with typical solution etching on prismatic layer (6, center 7) and large platy dolomite crystals.

Scale bars: $6.50 \mu \mathrm{m}$.

$$
\text { 7. } 10 \mu \mathrm{m} \text {. }
$$

Figure 8 Differential preservation of shell wall in one and the same foraminiferal test; upper left shows strongly corroded and partially dissolved microgranular layer and almost completely removed prismatic layer. Lower right: prismatic shell wall with solution etching pattern on microgranular layer. Note large dolomite crystal growing across shell wall. Scale bar, $20 \mu \mathrm{m}$.

Figures 9, 10 Planktonic foraminifer, shell wall is partially corroded, but partially the subrhombic and euhedral layers are well preserved.

Scale bars: $9.40 \mu \mathrm{m}$.

10. $10 \mu \mathrm{m}$.

Figures 11, 12 Solution etching on microgranular layer of planktonic foraminiferal test. Note large (0001) and small inclined rhombohedral (1014) crystal faces in dolomite in $\overline{1}$.

Scale bars: $11.10 \mu \mathrm{m}$.

12. $2 \mu \mathrm{m}$.

Figures 13, 14 Placoliths with syntaxial overgrowth on elements of distal central area and distal shield. Note absence of welding of the two shields in the small coccolith in Figure 14. Scale bars, $4 \mu \mathrm{m}$.

Figure 15 Discoasterid with overgrowth of syntaxial calcite cement. Scale bar, $4 \mu \mathrm{m}$.

Figure 16 Placolith partially enveloped or replaced by platy dolomite. Note large (0001) and small rhombohedral (1014) crystal faces in dolomite. Scale bar: $4 \mu \mathrm{m}$. 
PLATE 1
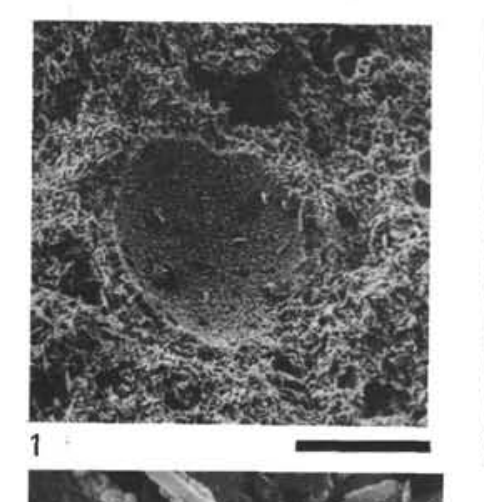
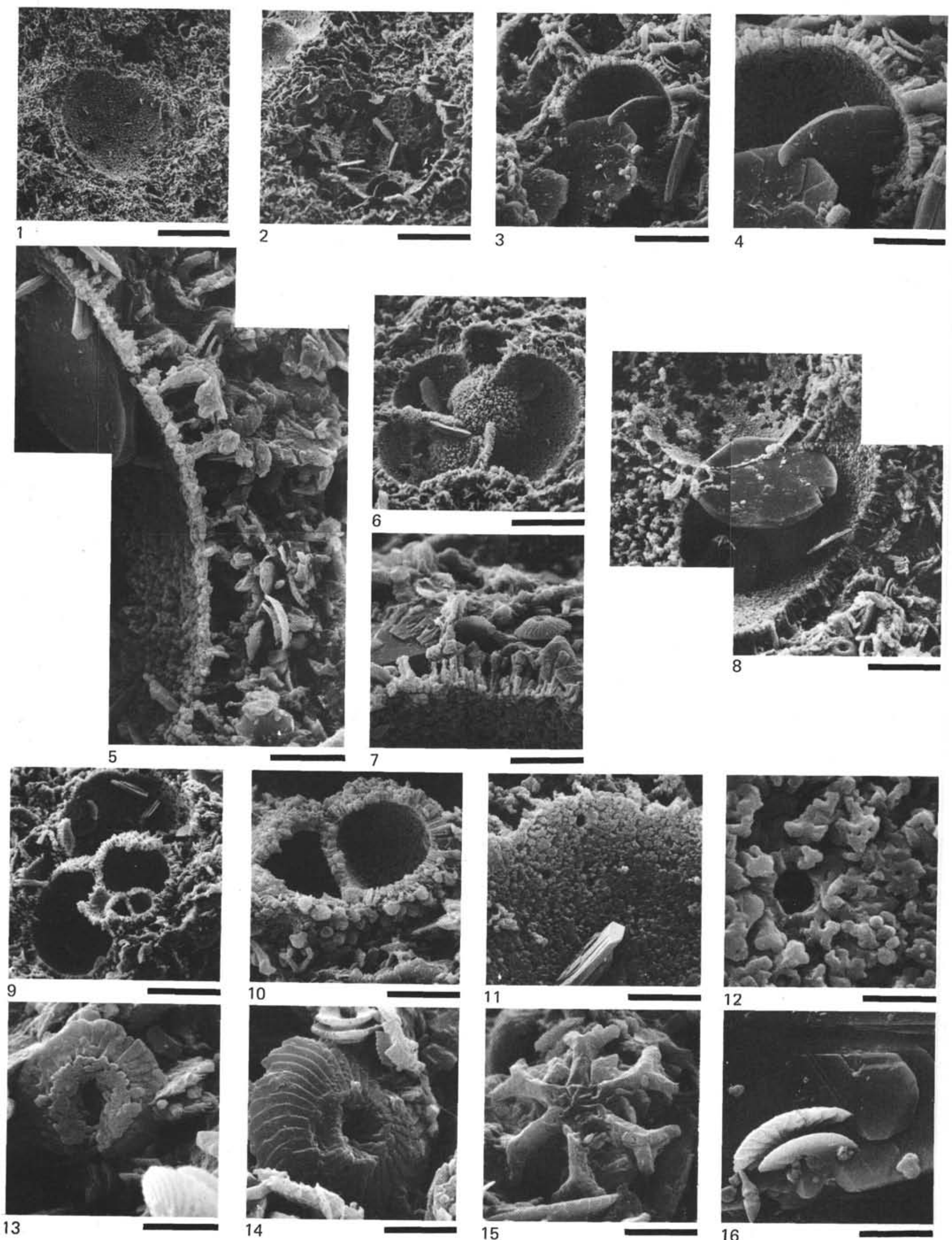
D. BERNOULLI, F. MÉLIĖRES

\section{PLATE 2}

Stereoscan electron micrographs of dolomitized pelagic limestone of lower Pliocene, Site 374, Core 11, Section 2.

Figures 1-6 Fine-grained dolomicrite consisting of euhedral platy dolomite crystals $\pm 10 \mu \mathrm{m}$ across with molds of planktonic foraminifera in which larger platy dolomite crystals have grown. Note well developed (0001) crystal faces. 1. Sample 374-11-2, 25-29 cm; 2-6. Sample 374-11-2, $66 \mathrm{~cm}$.

Scale bars: $1.100 \mu \mathrm{m}$.

2. $200 \mu \mathrm{m}$.

3. $100 \mu \mathrm{m}$.

4. $50 \mu \mathrm{m}$.

5. $100 \mu \mathrm{m}$.

6. $40 \mu \mathrm{m}$.

Figures 7-9 Dolomite crystals and framboidal pyrite in mold of planktonic foraminifer. Note the blocky habit of dolomite crystals and the more pronounced development of rhombohedral and prismatic crystal faces (cf. Plate 3, Figures 3, 4). Sample 374-11-2, 107-108 cm.

Scale bars: 7. $20 \mu \mathrm{m}$.

8, 9. $10 \mu \mathrm{m}$.

Figures 10-14. Molds of planktonic foraminifers lined by blocky dolomite crystals and pyrite framboids or scattered octahedra. Sample 374-11-2, $139 \mathrm{~cm}$;

Scale bars: 10, 13. $25 \mu \mathrm{m}$.

11, 14. $10 \mu \mathrm{m}$.

12. $20 \mu \mathrm{m}$.

Figures 15, 16 Blocky dolomite crystals with rhombohedral crystal faces lining mold of planktonic foraminifer. Sample 374-11-2, 147-149 cm; Scale bar: $10 \mu \mathrm{m}$. 
PLATE 2
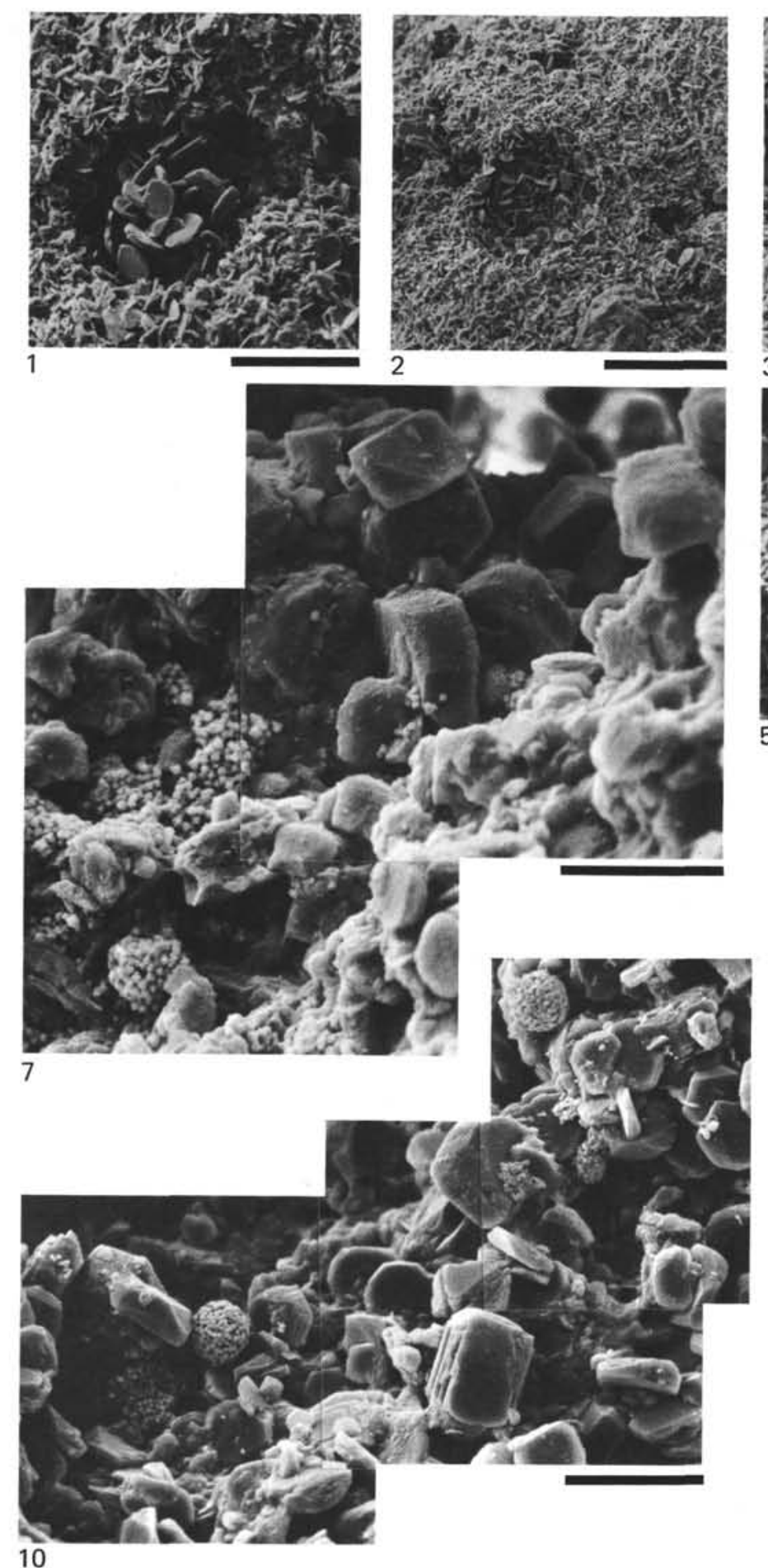

10
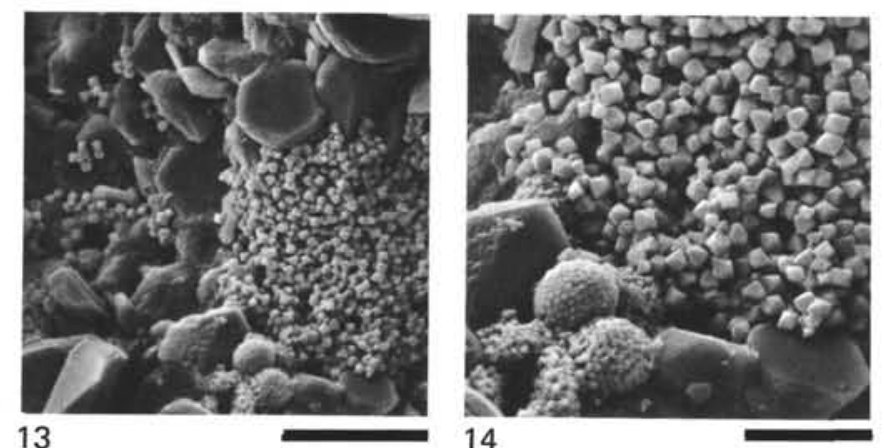
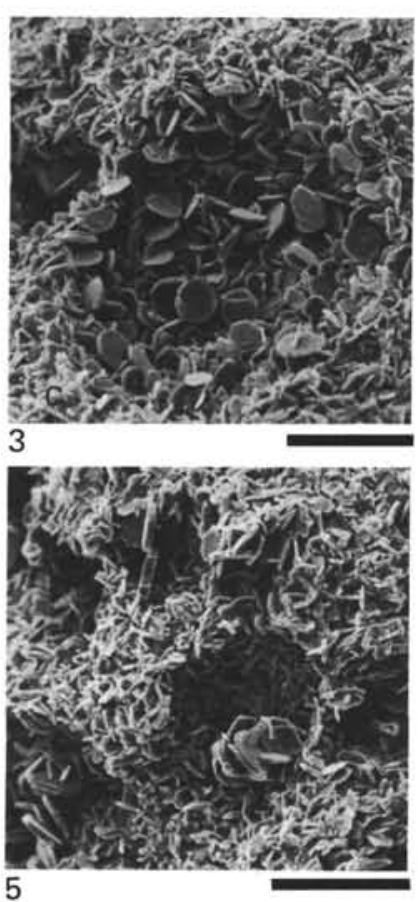

5
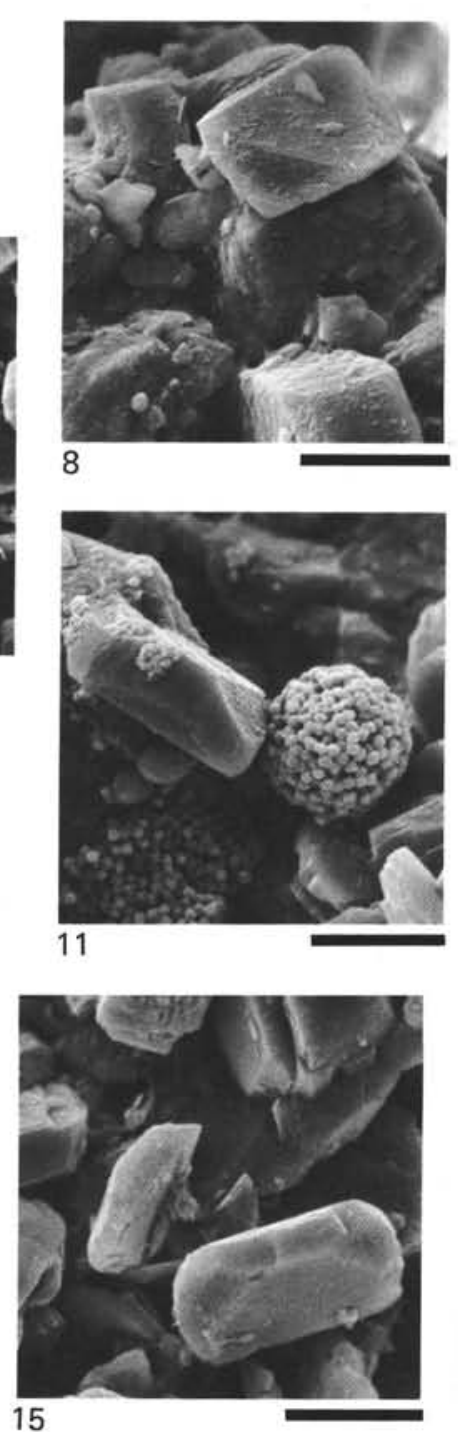
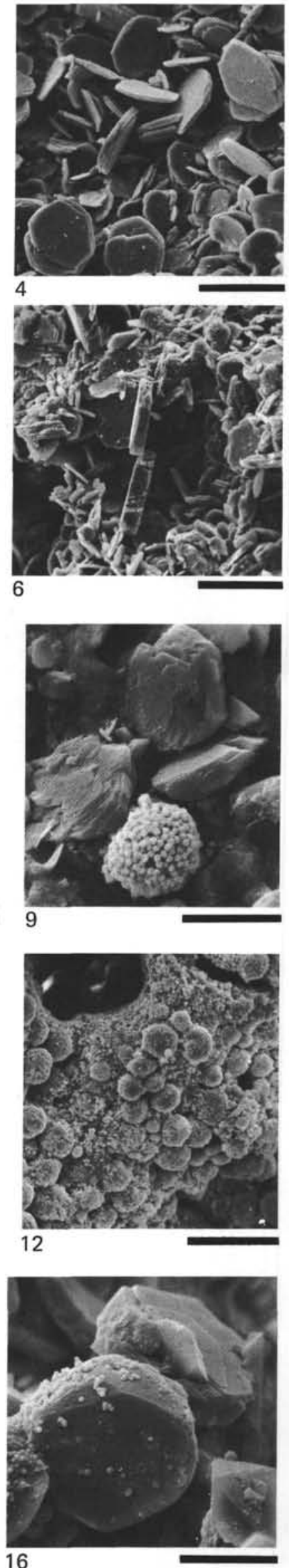
PLATE 3
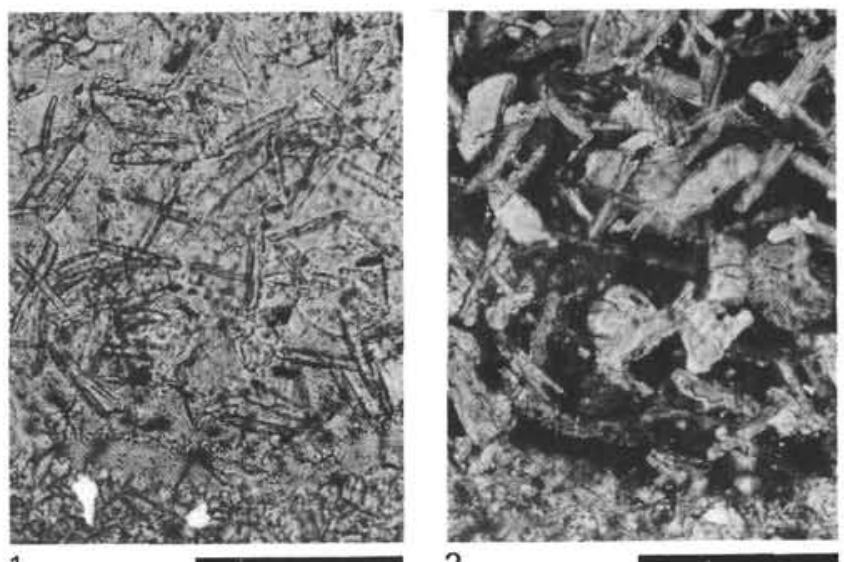

1
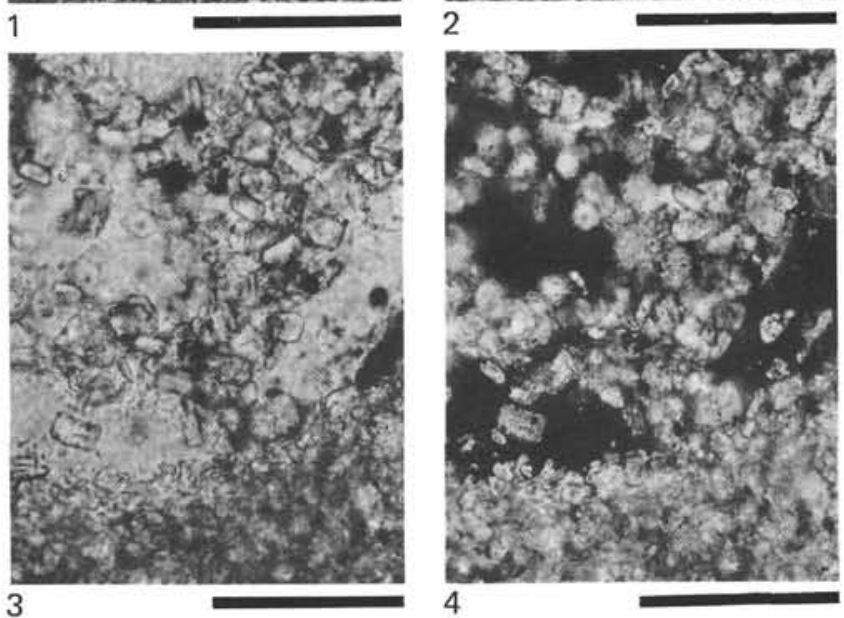

Figures 1, 2 Planktonic foraminifer with platy dolomite growing inside shell (cf. Plate 1). Sample 374-11-1, 107.5-110 cm, thin section.

Scale bar: $100 \mu \mathrm{m}$.

1. parallel nicols.

2. crossed nicols.

Figures 3, 4 Mold of planktonic foraminifer with dolomite crystals. These crystals have a more blocky habit with less developed faces and beginning rhombohedral (1014) crystal faces (cf. Plate 2, Figures 7, 8, 9) Sample 374-11-2, 107-108 cm, thin section.

Scale bar: $100 \mu \mathrm{m}$.

3. parallel nicols.

4. crossed nicols. 
PLATE 4

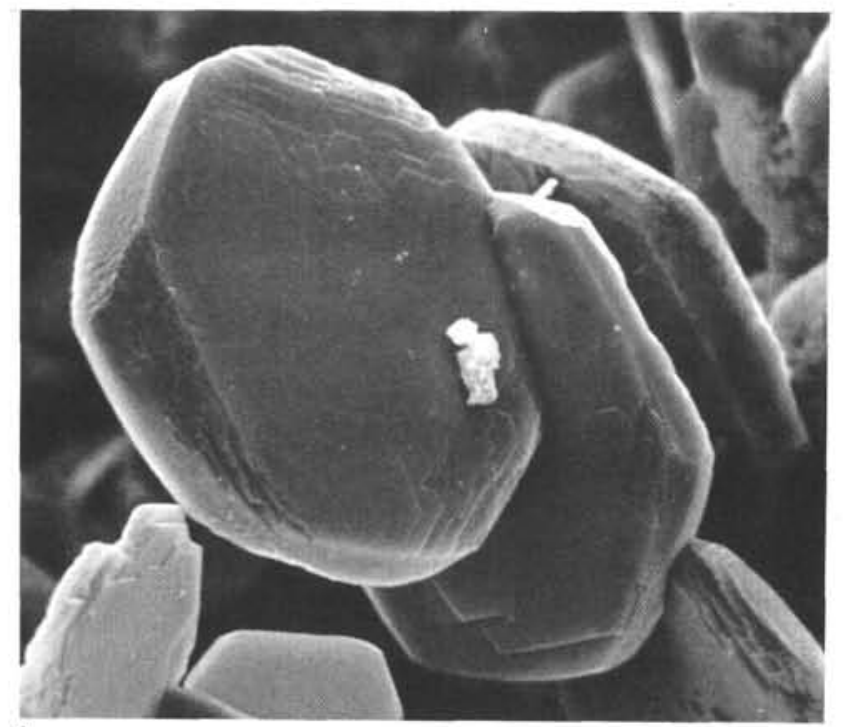

3
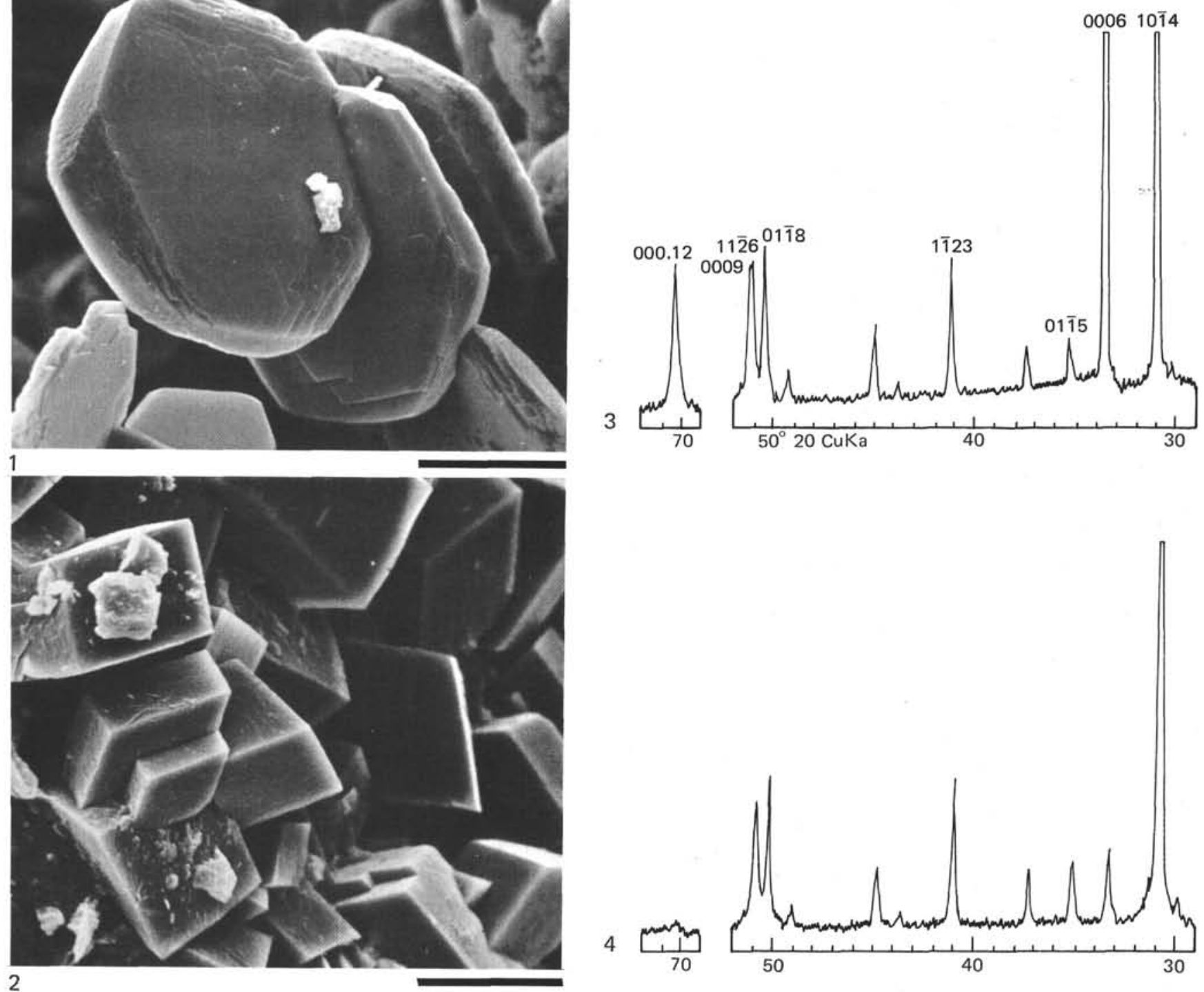

Crystal habit of dolomite

Figure 1 Platy dolomite with well developed (0001) faces. Note the foliaceous texture and the very imperfect hexagonal contour. Lower Pliocene, Sample 374-11-2, 25-26 cm, Ionian Abyssal Plain. Steroscan electron micrograph. Scale bars, $20 \mu \mathrm{m}$.

Figure 2 Rhombohedral dolomite, lower Pliocene, Sample 373A-2-2, 12-15 cm, Tyrrhenian Basin. Stereoscan electron micrograph. Scale bar, $20 \mu \mathrm{m}$.

Figure 3 X-ray powder diffractogram of platy dolomite in Figure 1. Note the very high intensity of $(00 \ell)$ reflections, especially (006) and (000.12). Note also the widening of the double peak (116)-(009) (for which $\Delta \mathrm{d}=0.005 \AA)$, due to important contribution in intensity by (009).

Figure 4 X-ray powder diffractogram of Rhombohedral dolomite in Figure 2. 